\title{
SPATIAL AND TEMPORAL DISTRIBUTION OF RAINFALL EROSIVITY IN BRAZILIAN AMAZONIA: A HYDROLOGICAL PERSPECTIVE BASED ON CMORPH TECHNIQUE
}

\author{
Jefferson Inayan de Oliveira Souto \\ Universidade Federal do Pará \\ Programa de Pós-Graduação em Ciências Ambientais - (PPGCA, UFPA) \\ inayansouto@gmail.com \\ Richard Reno da Costa Lobato \\ Universidade Federal de Santa Maria \\ Programa de Pós-Graduação em Meteorologia - (PPGMet, UFSM) \\ richardlobato7@gmail.com \\ Ilale Ferreira Lima \\ Universidade Federal do Pará \\ Programa de Pós-Graduação em Ciências Ambientais - (PPGCA, UFPA) \\ hilalebrades@hotmail.com \\ Greicy Kelly Pfeiff \\ Universidade Federal do Pará \\ Programa de Pós-Graduação em Ciências Ambientais - (PPGCA, UFPA) \\ greicypfeiff@gmail.com \\ Brenda Caroline Sampaio da Silva \\ Universidade Federal do Pará \\ Programa de Pós-Graduação em Ciências Ambientais - (PPGCA, UFPA) \\ brendacaroline444@gmail.com
}

\begin{abstract}
Rainfall erosivity is one crucial factor that controls soil erosion. The interannual variability of rainfall erosivity in Brazilian Amazonia connected to the El Niño-Southern Oscillation. This paper presents a study of the effects of Sea Surface Temperatures anomalies for El Niño region on rainfall erosivity in the Brazilian Amazonia. Rainfall erosivity across was assessed using 30 minutes rainfall data from Climate Prediction Center MORPHing technique during the period from 1998 to 2019. Results indicated that average rainfall erosivity is stronger during La Niña events and weaker during El Niño events. The annual value of rainfall erosivity ranged from 8241 to 24310 (Mj mm ha-1 h-1 year-1). Results also indicated that the effects of extending northward over Brazilian Amazonia showed a significant correlation $(P<0.05)$ between annual rainfall erosivity and annual precipitation. The El Niño-Southern Oscillation conditions was determined to exert the most substantial influence on rainfall erosivity. This information would be useful in the implementation of new soil conservation strategies.
\end{abstract}

Keywords: Rainfall variability. $\mathrm{R}$ fator. Remote sensing. Soil erosion.

\section{DISTRIBUIÇÃO ESPACIAL E TEMPORAL DA EROSIVIDADE DA CHUVA NA AMAZÔNIA BRASILEIRA: UMA PERSPECTIVA HIDROLÓGICA BASEADA NA TÉCNICA CMORPH}

\begin{abstract}
RESUMO
A erosividade das chuvas é um fator importante que controla a erosão do solo. A variabilidade interanual da erosividade das chuvas na Amazônia brasileira está ligada ao El Niño Oscilação Sul. Este artigo apresenta um estudo dos efeitos das anomalias da temperatura da superfície do mar na região Niño 3.4 sobre a erosividade das chuvas na Amazônia brasileira. A erosividade das chuvas foi avaliada usando dados de chuvas de 30 minutos da técnica Climate Prediction Center MORPHing no período de 1998 a 2019. Os resultados indicaram que a erosividade média anual das chuvas é mais forte durante os eventos de La Niña e mais fraca durante os eventos de El Niño. O valor anual da erosividade da chuva variou entre 8241 a 24310 (Mj mm ha-1 h-1 ano-1) Os resultados
\end{abstract}




\begin{abstract}
também indicaram que os efeitos de extensão para o norte sobre a Amazônia brasileira mostraram uma correlação significativa $(P<0,05)$ entre a erosividade anual da chuva e a precipitação anual. As condições do EI Niño Oscilação Sul foi determinante por exercer uma maior influência na erosividade da chuva. Esta informação será útil na implementação de novas estratégias de conservação do solo.
\end{abstract}

Palavras-chave: Variabilidade da precipitação. Fator R. Sensoriamento remoto. Erosão do solo.

\title{
INTRODUCTION
}

Soil degradation resulting from erosion by stormwater is perceived as one of the leading climate problems worldwide since it has significant environmental and economic impacts, especially in agricultural areas (VRIELING; HOEDJES; VAN DER VELDE, 2014; PANAGOS et al., 2015). One of the most critical factors in soil erosion by water is the erosive potential of raindrop impact. The rainfall erosivity factor $(R)$ in the Universal Soil Loss Equation (USLE) is generally of the best parameters for the prediction of the erosive potential of variations in intensity, duration, and frequency of impact of rainfall on soil (NEARING et al., 2017; BACK; GONÇALVES; FAN, 2019).

Likewise, besides being a significant driving factor of soil erosion, the R-factor can also be used to conclude about soil vulnerability, flood hazards, natural hazards, or probability of droughts (PANAGOS et al., 2015). Due to the importance of their evaluation in the impacts, it is critical to analyse rainfall data series with less than an hourly time resolution. An understanding of temporal and spatial characteristics of rainfall (e.g.; hourly, and monthly) is central to water resources planning and management, especially with evidence of climate change and variability in recent years. However, these data are scarce in many regions of the world (SADEGHI et al., 2017; DI RAIMO et al., 2018; DUULATOV et al., 2019).

In this context, rainfall retrievals from a satellite provide an alternative solution to this problem by providing spatially distributed rainfall estimation over large areas. Various aspects of remotely sensed rainfall have been explored and reported (ARVOR et al., 2017; OLIVEIRA et al., 2018; AWANGE; HU; KHAKI, 2019). For instance, Gama et al. (2016) show that the total bias and its different components of satellite-based rainfall data exhibit temporal variation in rainfall erosivity estimates in Eastern Amazon. The authors conclude that over local land areas Climate Prediction Center (CPC) MORPHing technique (CMORPH) bias mostly is very similar in the rain gauge, were a product very promise for use in water resources and hydrology applications. Besides, several studies investigated the accuracy of CMORPH (JOYCE et al., 2004) products across a range of space-time scales (BUARQUE et al., 2011; MASSARI; CROW; BROCCA, 2017; PEREIRA FILHO et al., 2018). In Amazonia, many studies consolidate include seasonal or daily estimates at $8 \mathrm{~km} \times 8 \mathrm{~km}$ spatial resolution (SOUTO et al., 2019; SOUTO; BELTRÃO; OLIVEIRA, 2019; SANTOS; VITORINO; PEREIRA, 2019), daily estimates at $0.25^{\circ} \times 0.25^{\circ}$ spatial resolution (RINGARD et al., 2015; ZUBIETA et al., 2017), and one-hourly estimates at $8 \mathrm{~km} \times 8 \mathrm{~km}$ (GERMANO et al., 2017).

In association with rainfall estimates, the amount of rainfall and the intensity of extreme rainfall appear to be changing in most areas of the world (WARD et al., 2014). Rainfall varies, as demonstrated by data on annual, seasonal, and other timescales of rainfall shown by Silva Junior et al. (2018). One crucial factor that has received persistent interest in the context of the variability of rainfall is the EI Niño Southern Oscillation (ENSO) which is an atmosphere and sea interaction that strongly affects the global climate. Although the ENSO occurs in the general area of the equatorial Pacific Ocean only, it can induce rainfall anomalies in most areas of the world (GÁRCIA-SERRANO et al., 2017; BUILESJARAMILLO; RAMOS; POVEDA, 2018). Thus, rainfall intensity and stability also tend to vary from one region to another because of regional differences and differences in rainfall types associated with the climate conditions of oceans.

Few studies have been performed on rainfall erosivity in Brazil using the CMORPH data, especially over Brazilian Amazonia (SANTOS SILVA et al., 2019). Therefore, this paper attempts to study the rainfall erosivity variations from 1998 through 2019 associated with ENSO events in Brazilian Amazonia. This region (northern, central and western portions) is mainly covered by original forest and receives high rainfall. The other half (the eastern, southern and southeastern areas) are where

$\begin{array}{llllll}\text { Caminhos de Geografia } \quad \text { Uberlândia-MG } & \text { v. 23, n. } 85 & \text { fev./2022 } & \text { p. 177-190 Página } 178\end{array}$


agribusiness activities currently take place, with weaker rainfall during less intensive times (GOMES et al., 2019). This study on the impact of the ENSO on rainfall erosivity in Brazilian Amazonia can provide a theoretical basis for the comprehensive treatment and prevention of soil erosion, and it has significant importance for the monitoring, evaluation, prediction, treatment of soil erosion, and climate change.

The objectives of this study were (a) to determine the R-factor for different climatic regions in Brazilian Amazonia, in order to create a spatially distributed rainfall erosivity map; and (b) to analyse the temporal distribution of rainfall erosivity associated of different types of ENSO conditions. We used satellite-based rainfall data from CMORPH over the Brazilian Amazonia.

\section{METHODOLOGY}

\section{Study area}

The Brazilian Amazonia covers an area of approximately $4.200 .000 \mathrm{~km}^{2}$, corresponding to $49 \%$ of the Brazilian territory (TEJADA et al., 2019). The Brazilian Amazon biome, within the Brazilian Legal Amazon encompasses totally or partially the states of Acre (AC), Amapá (AP), Amazonas (AM), Pará (PA), Roraima (RR), Rondônia (RO) Mato Grosso (MT), Maranhão (MA) and Tocantins (TO) (Figure 1). According to Köppen-Geiger climate classification the region is tropical (type $A$ ), but three subclimates can be identified: tropical rainforest (Af), tropical monsoon (Am) and tropical wet and dry $(A w)$. The average annual temperature is $25.0^{\circ} \mathrm{C}$ with small variations throughout the year (NOBRE et al., 2009).

The predominant vegetation types are Ombrophylous Dense Forest and Savanna with a diverse climate from tropical to monsoon climates (SOBRAL-SOUZA et al., 2018). According to KöppenGeiger climate classification the region is tropical (type A), but three sub-climates can be identified: tropical rainforest (Af), tropical monsoon (Am) and tropical wet and dry (Aw) (DUBREUIL et al., 2018). A suite of geographical, geomorphological, and climatic factors makes the Brazilian Amazonia an area with high precipitation. The average annual precipitation is on the order of $2.100 \mathrm{~mm}$, ranging from $3.200 \mathrm{~mm}$ in the west, due to the influence of the Andes, to values around 1,200 mm over the southeast and east of the Brazilian Amazonia, areas of intense land-use and land-cover change, known as "deforestation arc" (LEVY et al., 2018).

High precipitation rates are maintained both by moisture flows from evaporation in the tropical Atlantic Ocean and by forest evapotranspiration recycling (MOURA et al., 2019). Rainfall seasonality varies markedly across the basin: minimum monthly precipitation and short or absent dry season in the west and northwest, in contrast to a very seasonal regime in the south and southeast with longer dry seasons (MARINHO et al., 2020). Therefore, water erosion processes are dependent on hydrological and climatic conditions and can affect local ecology and the socioeconomic relationships of the Brazilian Amazonia.

Figure 1 - Location map of the Brazilian Amazonia. Percent tree cover based on the Global Forest Change Dataset (HANSEN et al., 2013). 


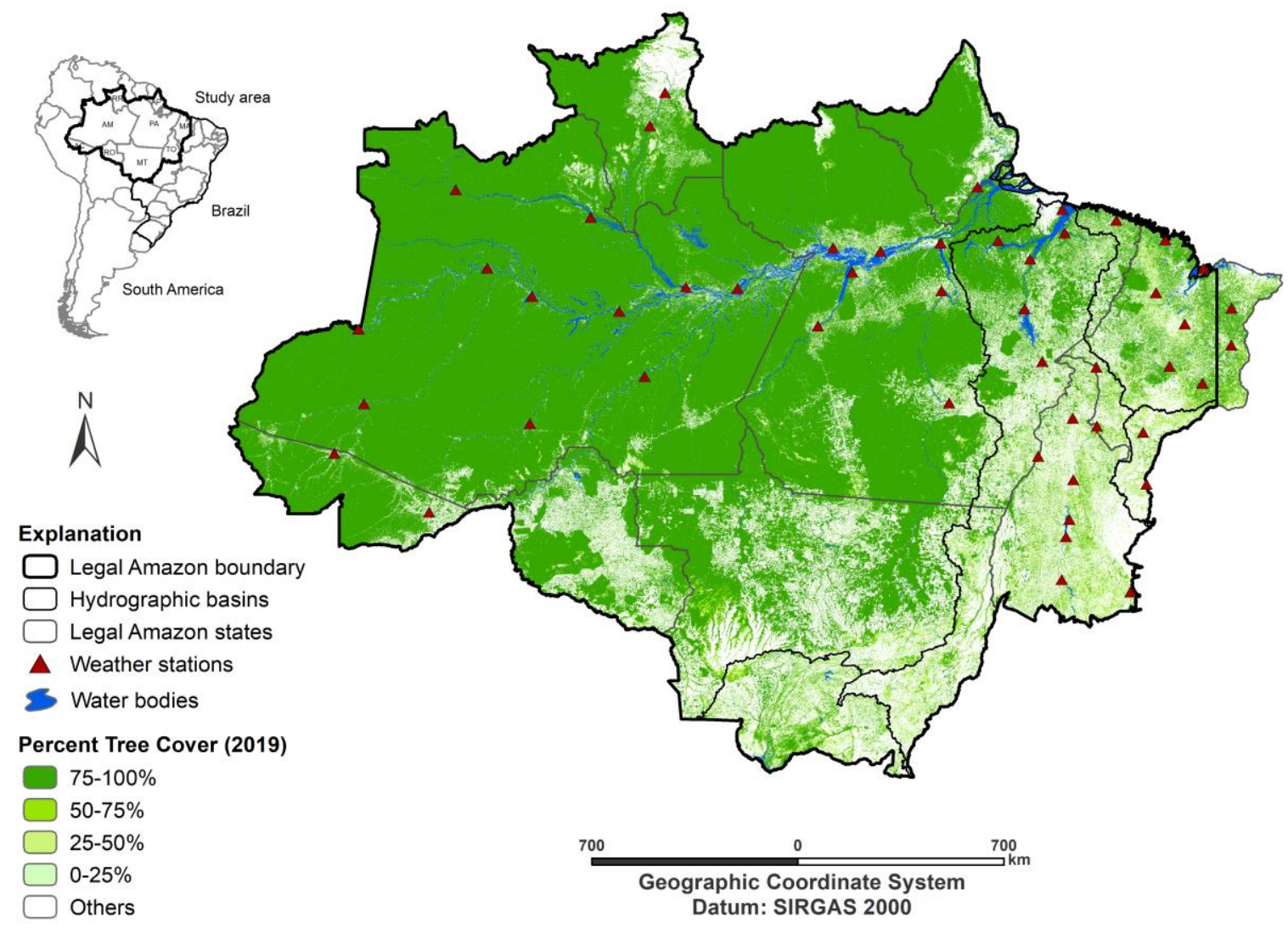

\section{CPC MORPHing technique}

CMORPH produces global rainfall analyses that include rainfall at $0.072^{\circ} \times 0.072^{\circ}$ spatial resolution ( $8 \mathrm{~km}$ at the equator) and 30 minutes temporal resolution (JOYCE et al., 2004). This technique uses rainfall estimates that have been derived from low orbiter satellite microwave observations exclusively, and whose features are transported via spatial propagation information that is obtained entirely from geostationary satellite infrared data. Rainfall estimates are derived from the passive microwaves aboard the multiple sensors. These estimates are generated by algorithms of Ferraro (1997) for SSM/I, Ferraro et al. (2000) for AMSU-B and Kummerow et al. (2001) for TMI.

Unlike meteorological products and applications derived from satellite-based rainfall data, CMORPH is not a rainfall estimation algorithm, but a means by which estimates from existing microwave rainfall algorithms can be combined. Therefore, this method is exceptionally flexible such that any rainfall estimates from any microwave satellite source can be incorporated. We use 21 years (June 1998 to May 2019) and the product used in this study were CMORPH Version 1.0. Meteorological data stations made available on the website of the National Institute of Meteorology (INMET) with less than 20\% missing monthly data from 1981 to 2019 were used to compare the results obtained by $\mathrm{CMORPH}$.

\section{Estimation of Rainfall Erosivity}

The rainfall $(R)$ factor from the Revised USLE (RUSLE) model was chosen to estimate the changes in rainfall erosivity. Rainfall erosivity was calculated using the rainfall values of gridded $\mathrm{CMORPH}$, comparing it with Gridded Daily Rainfall data. Renard and Freimund (1994) described the original method of calculating erosivity as:

$$
R=\frac{1}{n} \sum_{j=1}^{n} \sum_{k=1}^{m_{j}}\left(E I_{30}\right)
$$

$\begin{array}{lllll}\text { Caminhos de Geografia } & \text { Uberlândia-MG } & \text { v. 23, n. } 85 & \text { fev./2022 } & \text { p. 177-190 Página } 180\end{array}$


Where ${ }^{R}$ is the mean annual rainfall erosivity $\left(M J m m h^{-1} h^{-1} y e a r^{-1}\right), n$ is the number of years of data, $m_{i}$ is the number of erosive events in the $j^{j}$ year and $E I_{30}$ is the rainfall erosivity index. The events rainfall erosivity index $E I_{30}$ is defined as:

$E I_{30}=E I_{30}\left(\sum_{r=1}^{m} e_{r} v_{r}\right)$

Where $e_{r}$ is the unit rainfall energy $\left(M J \mathrm{ha}^{-1}\right)$ and $v_{r}$ is the rainfall depth $(\mathrm{mm})$ during a period ${ }^{r}$. $E I_{30}$ is the maximum rainfall intensity during a $30 \mathrm{~min}$ period of the rainfall event $\left(\mathrm{mm} \mathrm{h} \mathrm{h}^{-1}\right)$.

$e_{r}=0.29\left[1-0.072 \exp \left(-0.05 i_{r}\right)\right]$

Where $i_{r}$ is the rainfall intensity during the period $\left(m m h^{-1}\right)$.

The data used to derive $\mathrm{R}$ factor are gridded CMORPH data.

\section{RESULTS AND DISCUSSION}

In order to monitor the EI Niño and La Niña events, oceanic information is adopted, since it is considered a great precursor and essential to understanding these phenomena (JIMENEZ; LIBONATI; PERES, 2018). Events are defined as five consecutive overlapping three-month periods at or above the $+0.5^{\circ}$ anomaly for warm (El Niño) events and at or below the $-0.5^{\circ}$ anomaly for cold (La Niña) events, in other words, when the index is positive, the temperature of the Pacific Ocean is higher than Normal, and for the negative index, the opposite occurs (Figure 2). By obtaining the three-month mean Sea Surface Temperature (SST) anomaly, we demonstrate to know if El Niño and La Niña events are occurring or not. The absence of either condition is called a Normal year.

Figure 2 - Monthly area average SST anomalies over the Niño 3.4 region $\left(5^{\circ} \mathrm{S}-5^{\circ} \mathrm{N}, 170^{\circ}-120^{\circ} \mathrm{W}\right)$ based on the January 1998 to September 2019 period. Monthly average taken from the NOAA Extended Reconstructed SST V5 (HUANG et al., 2017). Anomalies are calculated by removing the 1981-2010 monthly mean from individual months. Acronyms indicate the ENSO conditions based the Oceanic Niño Index value: W (Weak), M (Moderate), S (Strong) and VS (Very Strong).

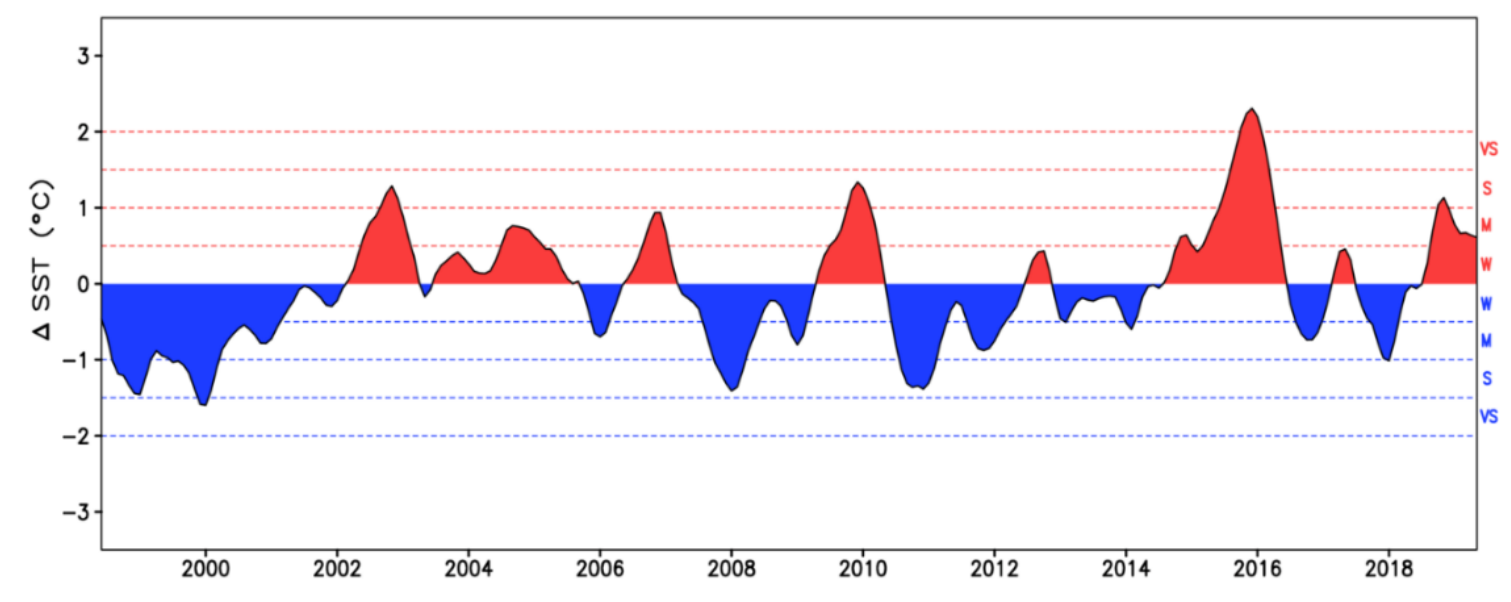

The overall evaluation and comparison summary, shown in Figure 3, indicates that CMORPH has a high level of correspondence with rain gauge observations and may have a useful skill for various functions in the study area. The plot in Figure $3 \mathrm{a}$ and Figure $3 \mathrm{~b}$ further reveals that CMORPH is very close to the rain gauge observation at all rainfall measurement values, except for low rainfall $(<40 \mathrm{~mm})$ and rainfall between $(180$ to $220 \mathrm{~mm})$ accumulation, respectively, where they show a slight overestimation. Thus, from the annual rainfall data along years (1998-2019) for Brazilian Amazonia (Figure $3 \mathrm{c}$ ) was observed ten most significant years of rainfall. During this time period, six were

$\begin{array}{llllll}\text { Caminhos de Geografia } & \text { Uberlândia-MG } & \text { v. 23, n. } 85 & \text { fev./2022 } & \text { p. 177-190 } & \text { Página } 181\end{array}$


observed in the presence of La Niña, one in El Niño and three during Normal periods, being: 2003.74 mm (1998-1999),1934.00 mm (1999-2000), 2052.26 mm (2000-2001), $1914.76 \mathrm{~mm}$ (2007-2008), 2062.85 mm (2008-2009), 1892.00 mm (2010-2011), 1958.11 mm (2002-2003), 2012.44 mm (20012002), $2071.10 \mathrm{~mm}$ (2003-2004) and $1931.42 \mathrm{~mm}$ (2013-2014), respectively.

For the years showing the presence of the El Niño event, the values decreased in comparison with the Normal periods, with precipitation varying from $1494.03 \mathrm{~mm}$ to $1958.11 \mathrm{~mm}$. These results correspond to a decrease in the average about the Normal and La Niña conditions. It can be observed that during the rainier and less rainy years there were increases of up to $209.83 \mathrm{~mm}$ and decreases of 358.98 $\mathrm{mm}$. Besides, it may be mentioned that during the El Niño year of 2015-2016, experienced severe drought to less rainfall in Brazilian Amazonia as documented in Jimenez-Muñoz et al. (2016).

Figure 3 - $(a, b)$ comparison of the satellite product at gauge-based monthly rainfall data and (c) temporal variation of annual rainfall over Brazilian Amazonia derived by CMORPH and historical gauge-based rainfall data $(n=35)$, also showing the mean annual rainfall (dashed line). Note that the $r^{2}$ is the correlation coefficient. All the years were represented of the ENSO conditions: La Niña (blue) and El Niño (red).
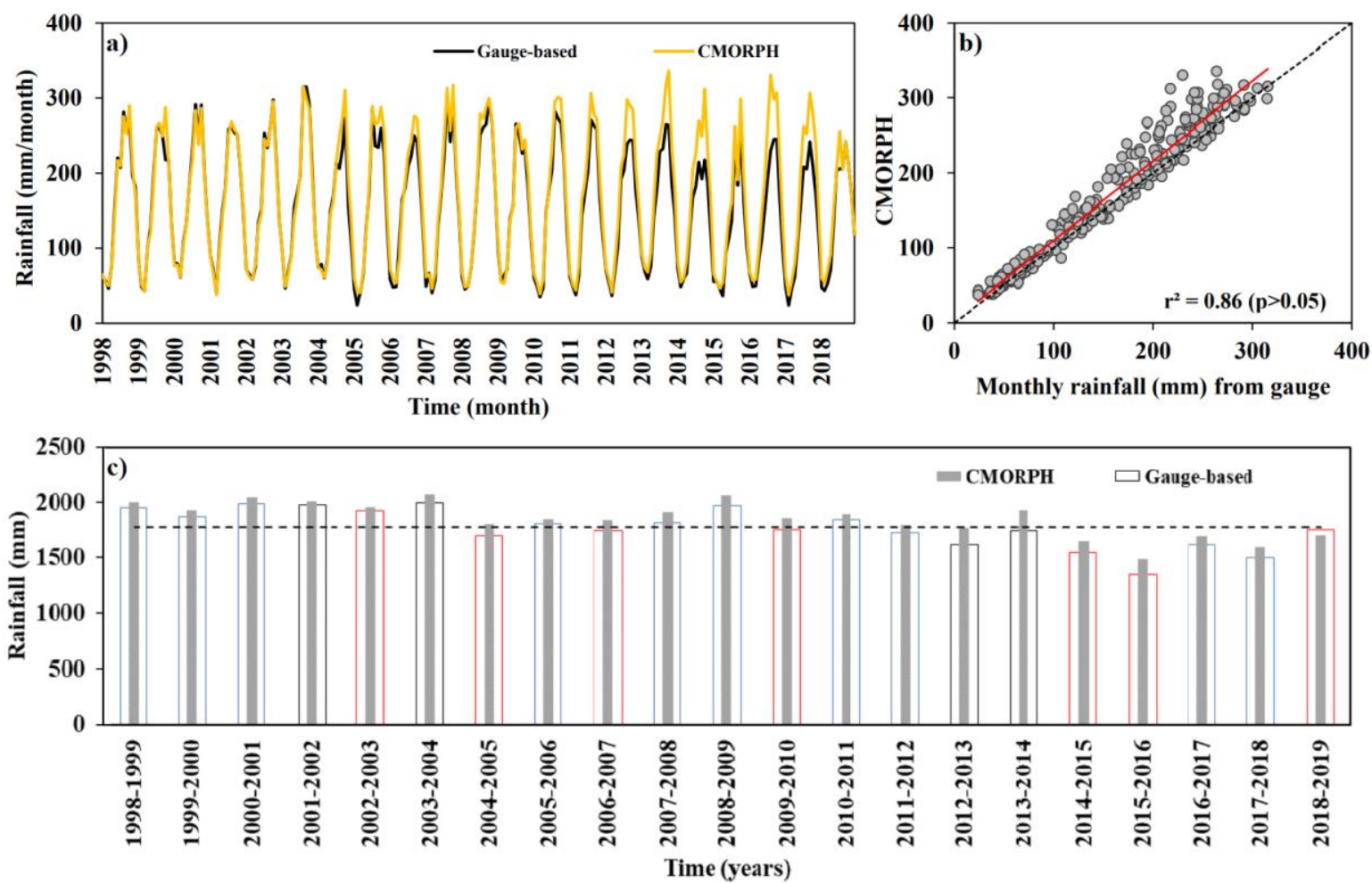

Spatial analysis of available rainfall revealed similar spatial patterns for the La Niña and Normal conditions compared to characteristics of El Niño (Figure 4), where the region of highest rainfall (> $2.600 \mathrm{~mm}$ ) extend northward, while the regions of the moderate amount of rainfall remained relatively stable during occurrence La Niña events. Since most rain events occur during the rainy season, it is expected that annual accumulated were mostly driven by the convective systems from the Atlantic Ocean (MARTINS et al., 2015). However, the areas of low rainfall are markedly diminished during the El Niño episodes, also affecting other regions of intense convection. Generally, the wet and dry conditions over Brazilian Amazonia is due to an increase and decreased annual accumulated rainfall, associated with a warming of the equatorial Pacific and a sustained cooling of northern tropical Atlantic Ocean (TORRALBA et al., 2015; GARCÍA-SERRANO et al., 2017). 
Figure 4 - Rainfall accumulated maps for Brazilian Amazonia derived by CMORPH. The following years were accumulated to base Oceanic Niño Index. All the years were represented of the ENSO conditions: La Niña (blue) and El Niño (red).

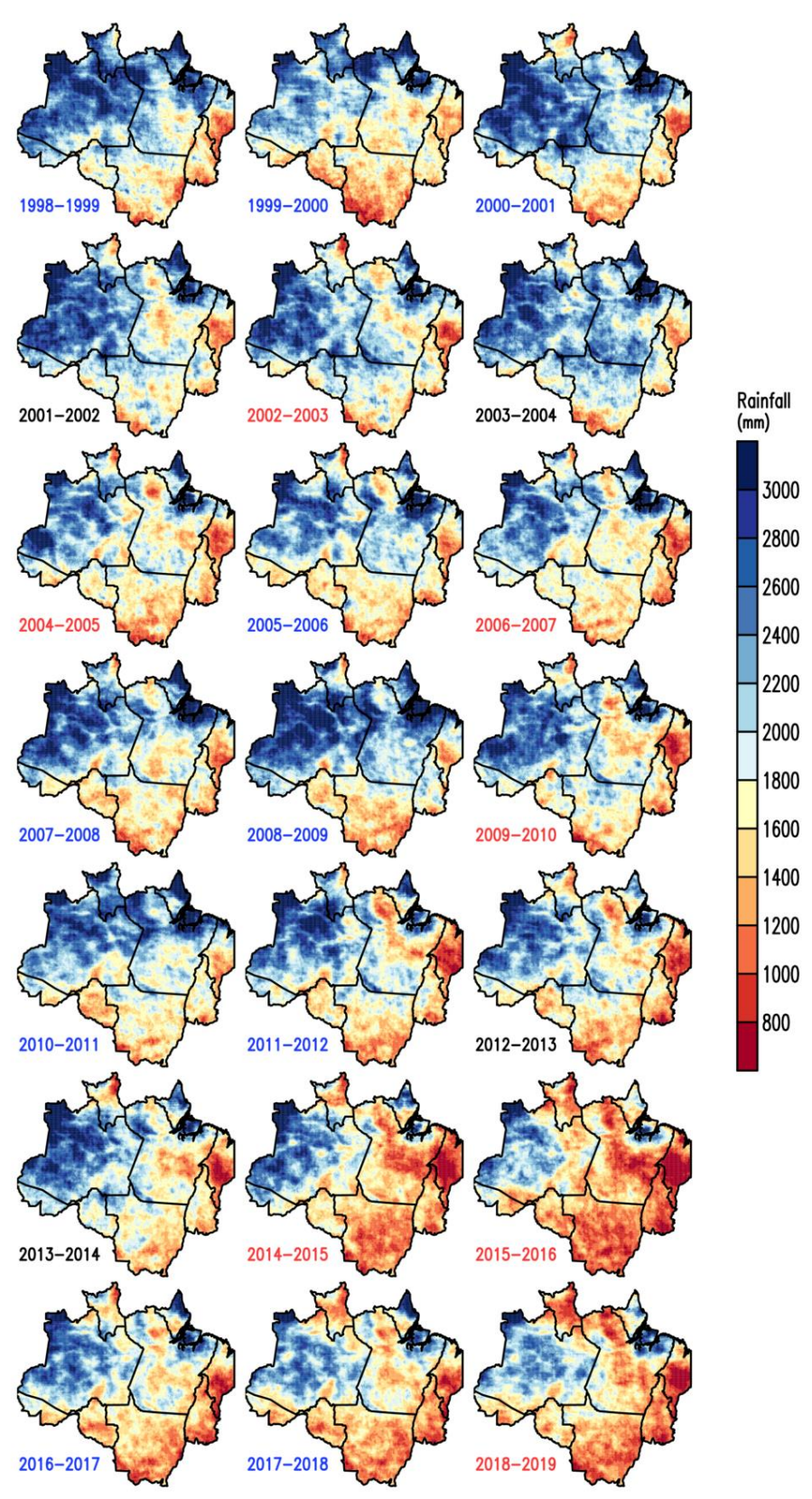

Analyzing the maps presented in Figure 5, the rainfall erosivity indicates that the general trend is an increase accompanied by fluctuations during Normal and La Niña conditions. We can also see from the rainfall erosivity decrease was mainly in decrease annual rainfall after 2012-2013 and entered a decline stage after 2014-2015. Results for the intensity of rainfall erosivity indicated lower rainfall erosivity during the period from 2014-2015, 2015-2016, 2017-2018 and 2018-2019 during EI Niño events. By contrast, rainfall erosivity was significantly high during the successive La Niña events spanning 1998-2001, mainly extend to the northward region of the Brazilian Amazonia. This way, in some regions the annual erosivity normally is incipient and others are extremely high (almost ten times more erosive than the areas with lowest erosivity).

$\begin{array}{lllll}\text { Caminhos de Geografia } & \text { Uberlândia-MG } & \text { v. 23, n. } 85 & \text { fev./2022 } & \text { p. 177-190 Página } 183\end{array}$


It should be noted that spatial distribution of the rainfall erosivity might be partly attributed to the interaction between negative SST and seasonal rainfall, where is possible to observe that there was a reduced number of rainfall events, rainfall depth and rainfall erosive power. In recent years, the number of ENSO intensity were highly significant, which means the El-Niño episodes have a greater impact on the local climate in Brazilian Amazonia, according to Moura et al. (2019). The ENSO conditions suggest that both the amount and the intensity of rainfall are decreasing and varying in some areas of the Brazilian Amazonia, which is in a good agreement with the studies conducted for Eastern Amazonia (CAVALCANTE et al., 2020). Besides, a special attention should be given to the topographic factor, since it characterizes the surface runoff speed, in other words, it is a good indication of soil erosion risk (CORREA et al., 2016). According to Correa et al. (2016), these areas can be considered as high vulnerability to erosion, thus conservation practices are generally encouraged in order to reduce runoff energy gain due to the topography.

Figure 5 - Rainfall erosivity maps for Brazilian Amazonia derived by CMORPH. The following years were averaged to derive the Oceanic Niño Index. All the years were represented of the ENSO conditions: La Niña (blue) and El Niño (red). 


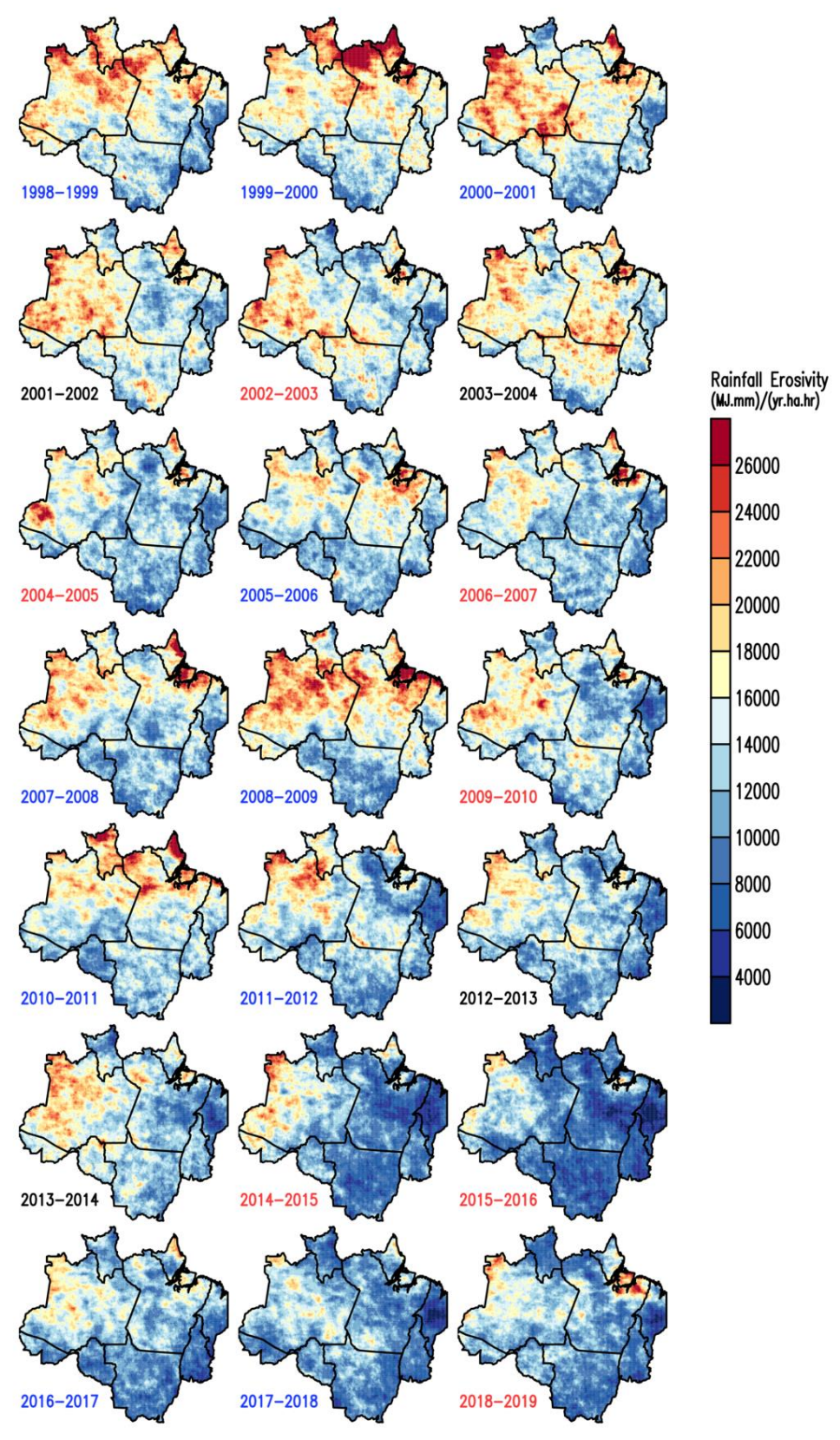

Due to high variation of vegetation and soils in Brazilian Amazonia, a high variability of responses to erosive processes and sediment yields can also be implied (RIQUETTI et al., 2020). In the regions where the dry season is more pronounced (like in the southeastern region in Brazilian Amazonia), a major part of the soils is bare during this period. At the beginning of the wet season, torrential rains may occur with high erosive effects with a strong performance of mesoscale/synoptic convective systems and their associations with the South Atlantic convergence zone (SACZ), which modulate the maximum precipitation during the summer months (MARINHO et al., 2020).

Therefore, it should be stressed that rainfall erosivity estimates were statistically significant for each region in comparison with the ones found by Oliveira; Wendland; Nearing (2013) and Trindade et al. (2016). Thus, satellite-based rainfall data indicating a great potential to estimates the spatial relationship between annual rainfall erosivity and mean annual rainfall (PANAGOS et al., 2017; TENG et al., 2017). This is particularly important for the factors that compose the RUSLE, where rainfall is the driving force of erosion and has a direct influence on aggregate breakdown and runoff. Erosivity is 
also an essential parameter for soil erosion risk assessment under future land use and climate change discussed in Almagro et al. (2017) and Terassi et al. (2020).

On the other hand, Riquetti et al. (2020) showed an increase in the frequency and magnitude of soil erosion in South America, mainly Brazilian Amazonia, and attributed it to a rise in extreme rainfall events. Santos Silva et al. (2019) also pointed out that a local increase in the frequency or intensity of extreme rainfall events could further result in soil degradation. These findings confirmed the strong role of extreme precipitation in regional and local soil erosion control, land management, and agricultural production.

\section{CONCLUSIONS}

In this research, we estimated the rainfall erosivity in Brazilian Amazonia using as primary data sources the CMORPH. Although the rainfall erosivity estimates are based on many uncertainties, these spatial estimation highlights the areas where rainfall erosivity has a high rate of natural and accelerated erosion. Besides, we investigated the influence of the Niño3.4 SST anomaly on rainfall erosivity in Brazilian Amazonia as representations of ENSO phenomena. Rainfall erosivity in Brazilian Amazonia appeared to be more severe during La Niña events and less severe during El Niño events. We can conclude that soil erosion may become serious during La Niña events but not during El Niño events in the studied all areas.

Based on these maps combined with other information, strategies can be defined to minimise erosion is a function of rainfall intensity and to reduce offsite impacts of these associated with land use and land cover change. Thus, the rainfall erosivity maps are useful to illustrate how rainfall influences soil erosion and represent an essential source of information to predict erosion in tropical regions. The findings of this study have several important implications for soil conservation planning over Brazilian Amazonia.

\section{ACKNOWLEDGMENTS}

The authors are grateful for financial support from the National Council for the Improvement of Higher Education (CAPES) and Environmental Science Graduate Program (PPGCA) at Federal University of Pará (UFPA). We also thank the National Oceanic and Atmospheric Administration for the provision of CMORPH data and INMET network of surface observations.

\section{REFERENCES}

ALMAGRO, A.; OlIVEIRA, P. T. S.; NEARING, M. A.; HAGEMANN, S. Projected climate change impacts in rainfall erosivity over Brazil. Scientific Reports, v. 7, n. 1, p. 1-12, 2017. https://doi.org/10.1038/s41598-017-08298-y

ARVOR, D.; FUNATSU, B.; MICHOT, V.; DUBREUIL, V. Monitoring Rainfall Patterns in the Southern Amazon with PERSIANN-CDR Data: Long-Term Characteristics and Trends. Remote Sensing, v. 9, n. 3, p. 889-910, 2017. https://doi.org/10.3390/rs9090889

AWANGE, J. L.; HU, K. X.; KHAKI, M. The newly merged satellite remotely sensed, gauge and reanalysis-based Multi-Source Weighted-Ensemble Precipitation: Evaluation over Australia and Africa (1981-2016). Science of The Total Environment, v. 620, n. 1, p. 448-465, 2019. https://doi.org/10.1016/i.scitotenv.2019.03.148

BACK, A. J.; GONÇALVES, F. N.; FAN, F. M. Spatial, seasonal, and temporal variations in rainfall aggressiveness in the south of Brazil. Engenharia Agrícola, Jaboticabal, v. 39, n. 4, p. 466-475, 2019. https://doi.org/10.1590/1809-4430-Eng.Agric.v39n4p466-475/2019

BUARQUE, D. C.; DE PAIVA, R. C. D.; CLARKE, R. T.; MENDES, C. A. B. A comparison of Amazon rainfall characteristics derived from TRMM, CMORPH and the Brazilian national rain gauge network. Journal of Geophysical Research, v. 116, n. 19, p. 1-12, 2011. https://doi.org/10.1029/2011jd016060

$\begin{array}{lllll}\text { Caminhos de Geografia } & \text { Uberlândia-MG } & \text { v. 23, n. } 85 & \text { fev./2022 } & \text { p. 177-190 Página } 186\end{array}$


BUILES-JARAMILLO, A.; RAMOS, A. M. T.; POVEDA, G. Atmosphere-Land Bridge between the Pacific and Tropical North Atlantic SST's through the Amazon River basin during the 2005 and 2010 droughts. Chaos: An Interdisciplinary Journal of Nonlinear Science, v. 28, n. 8, p. 1-12, 2018. https://doi.org/10.1063/1.5020502

CAVALCANTE, R. B. L.; FERREIRA, D. B. S.; PONTES, P. R. M.; TEDESCHI, R. G.; COSTA, C. P. W.; SOUZA, E. B. Evaluation of extreme rainfall indices from CHIRPS precipitation estimates over the Brazilian Amazonia. Atmospheric Research, v. 238, n. 1, p. 1-12, 2020. https://doi.org/10.1016/i.atmosres.2020.104879

CORREA, S. W.; MELLO, C. R.; CHOU, S. C.; CURI, N.; NORTON, L. D. Soil erosion risk associated with climate change at Mantaro River basin, Peruvian Andes. CATENA, v. 147, n. 2, p. 110-124, 2016. https://doi.org/10.1016/j.catena.2016.07.003

DI RAIMO, L. A. D. L.; AMORIM, R. S. S.; COUTO, E. G.; NÓBREGA, R. L. B.; TORRES, G. N.; BOCUTI, E. D.; ... RODRIGUES, R. V. Spatio-temporal variability of erosivity in Mato Grosso, Brazil. Ambiente e Agua - An Interdisciplinary Journal of Applied Science, v. 13, n. 6, p. 1-14, 2018. https://doi.org/10.4136/ambi-agua.2276

DUBREUIL, V.; FANTE, K. P.; PLANCHON, O.; SANT'ANNA NETO, J. L. Climate change evidence in Brazil from Köppen's climate annual types frequency. International Journal of Climatology, v. 39, n. 3, p. 1446-1456, 2018. https://doi.org/10.1002/joc.5893

DUULATOV, E.; CHEN, X.; AMANAMBU, A. C.; OCHEGE, F. U.; OROZBAEV, R.; ISSANOVA, G.; OMURAKUNOVA, G. Projected Rainfall Erosivity Over Central Asia Based on CMIP5 Climate Models. Water, v. 11, n. 5, p. 897-911, 2019. https://doi.org/10.3390/w11050897

FERRARO, R. R. Special Sensor Microwave Imager Derived Global Rainfall Estimates For Climatological Applications. Journal of Geophysical Research, v. 102, n. 4, p. 16715-16735, 1997. https://doi.org/10.1029/97JD01210

FERRARO, R.R.; WENG, F.; GRODY, N. C.; ZHAO, L. Precipitation Characteristics Over Land From the NOAA-15 AMSU Sensor. Geophysical Research Letters, v. 27, n. 7, p. 2669-2672, 2000. https://doi.org/10.1029/2000GL011665

GAMA, A. G.; SOUZA, A. M. L.; COSTA, J. A.; SOUZA, E. B. Rainfall erosivity in Rondon do Pará, PA, Brazil from 1995 to 2015 and projected to 2035. Ambiente e Agua - An Interdisciplinary Journal of Applied Science, v. 11, n. 4, p. 1006-1021, 2016. https://doi.org/10.4136/ambi-agua.1956

GARCÍA-SERRANO, J.; CASSOU, C.; DOUVILLE, H.; GIANNINI, A.; DOBLAS-REYES, F. J. Revisiting the ENSO Teleconnection to the Tropical North Atlantic. Journal of Climate, v. 30, n. 17, p. 6945-6957, 2017. https://doi.org/10.1175/jcli-d-16-0641.1

GERMANO, M. F.; VITORINO, M. I.; COHEN, J. C. P.; COSTA, G. B.; SOUTO, J. I. DE O.; REBELO, M. T. C.; DE SOUSA, A. M. L. Analysis of the breeze circulations in Eastern Amazon: an observational study. Atmospheric Science Letters, v. 18, n. 2, p. 67-75, 2017. https://doi.org/10.1002/asl.726

GOMES, V. H. F.; VIEIRA, I. C. G.; SALOMÃO, R. P.; TER STEEGE, H. Amazonian tree species threatened by deforestation and climate change. Nature Climate Change, v. 9, n. 7, p. 547-553, 2019. https://doi.org/10.1038/s41558-019-0500-2

HANSEN, M. C.; POTAPOV, P. V.; MOORE, R.; HANCHER, M.; TURUBANOVA, S. A.; TYUKAVINA, A.; ... TOWNSHEND, J. R. G. High-Resolution Global Maps Of 21st-Century Forest Cover Change. Science, v. 342, n. 6160, p. 850-853, 2013. https://doi.org/10.1126/Science.1244693

HUANG, B.; THORNE, P. W.; BANZON, V. F.; BOYER, T.; CHERUPIN, G.; LAWRIMORE, J. H.; ... ZHANG, H. M. Extended reconstructed sea surface temperature, version 5 (ERSSTv5): Upgrades, validations, and intercomparisons. Journal of Climate, v. 30, n. 20, p. 8179-8205, 2017. https://doi.org/10.1175/jcli-d-16-0836.1

JIMENEZ, J. C.; LIBONATI, R.; PERES, L. F. Droughts over Amazonia in 2005, 2010, and 2015: a cloud cover perspective. Frontiers in Earth Science, v. 6, n. 227, p. 1-7, 2018. https://doi.org/ $\underline{10.3389 / \text { feart.2018.00227 }}$ 
JIMÉNEZ-MUÑOZ, J. C.; MATTAR, C.; BARICHIVICH, J.; SANTAMARÍA-ARTIGAS, A.; TAKAHASHI, K.; MALHI, Y.; ... SCHRIER, G. Record-breaking warming and extreme drought in the Amazon rainforest during the course of El Niño 2015-2016. Scientific Reports, v. 6, n. 1, p. 1-7, 2016. https://doi.org/10.1038/srep33130

JOYCE, R. J.; JANOWIAK, J. E.; ARKIN, P. A.; XIE, P. CMORPH: A Method That Produces Global Precipitation Estimates From Data At High Spatial And Temporal Resolution. Journal of Hydrometeorology, v. 5, n. 2, p. 487-503, 2004. https://doi.org/10.1175/15257541(2004)005<0487:CAMTPG>2.0.CO;2

KUMMEROW, C.; HONG, Y.; OLSON, W.S.; YANG, S.; ADLER, R.F.; MCCOLLUM, J.; FERRARO, R.; PETTY, G.; SHIN, D-B.; WILHEIT, T. T. The Evolution of the Goddard Profiling Algorithm (GPROF) for Rainfall Estimation from Passive Microwave Sensors. Journal of Applied Meteorology, v. 40, n. 3, p. 1801-1820, 2001. https://doi.org/10.1175/1520-0450(2001)040<1801:TEOTGP >2.0.CO;2

LEVY, M. C.; LOPES, A. V.; COHN, A.; LARSEN, L. G.; THOMPSON, S. E. Land use change increases streamflow across the arc of deforestation in Brazil. Geophysical Research Letters, v. 45, n. 8, p. 3520-3530, 2018. https://doi.org/10.1002/2017gl076526

MARINHO, K. F. S.; ANDRADE, L. M. B.; SPYRIDES, M. H. C.; SANTOS E SILVA, C. M.; OLIVEIRA, C. P.; BEZERRA, B. G.; MUTTI, P. R. Climate profiles in Brazilian microregions. Atmosphere, v. 11, n. 11, p. 1217-1229, 2020. https://doi.org/10.3390/atmos11111217

MARTINS, G.; VON RANDOW, C.; SAMPAIO, G.; DOLMAN, A. J. Precipitation in the Amazon and its relationship with moisture transport and tropical Pacific and Atlantic SST from the CMIP5 simulation. Hydrology and Earth System Sciences, v. 12, n. 2, p. 671-704, 2015. https://doi.org/ 10.5194/hessd-12-671-2015

MASSARI, C.; CROW, W.; BROCCA, L. An assessment of the performance of global rainfall estimates without ground-based observations. Hydrology and Earth System Sciences, v. 21, n. 9, p. 4347-4361, 2017. https://doi.org/10.5194/hess-21-4347-2017

MOURA, M. M.; DOS SANTOS, A. R.; DA SILVA, S. F.; PIMENTEL, S. M.; DE ANDRADE, M. S. S.; SILVA, F. G. R.; ... DE CARVALHO, J. R. Relation of El Niño and La Niña phenomena to precipitation, evapotranspiration and temperature in the Amazon basin. Science of The Total Environment, $v$. 651, n.1, p. 1639-1651, 2019. https://doi.org/10.1016/j.scitotenv.2018.09.242

NEARING, M. A.; YIN, S.; BORRELLI, P.; POLYAKOV, V. O. Rainfall erosivity: An historical review. CATENA, v. 157, n. 2, p. 357-362, 2017. https://doi.org/10.1016/j.catena.2017.06.004

NOBRE, C.A.; OBREGÓN, G.O.; MARENGO, J.A.; FU, R.; POVEDA, G. Characteristics of Amazonian climate: Main features. In Amazonia and Global Change; Keller, M.; Bustamante, M.; Gash, J.; Dias, P.S.; Eds.; American Geophysical Union: Washington, DC, USA, 2009 p. 368-374.

OLIVEIRA, P. T. S.; WENDLAND, E.; NEARING, M. A. Rainfall erosivity in Brazil: A review. CATENA, v. 100, n. 1, p. 139-147, 2013. https://doi.org/10.1016/j.catena.2012.08.006

OLIVEIRA, R.; MAGGIONI, V.; VILA, D.; PORCACCHIA, L. Using Satellite Error Modeling to Improve GPM-Level 3 Rainfall Estimates over the Central Amazon Region. Remote Sensing, v. 10, n. 2, p. 336-347, 2018. https://doi.org/10.3390/rs10020336

PANAGOS, P.; BALLABIO, C.; BORRELLI, P.; MEUSBURGER, K.; KLIK, A.; ROUSSEVA, S.; .. ALEWELL, C. Rainfall erosivity in Europe. Science of The Total Environment, v. 511, n. 2, p. 801814, 2015. https://doi.org/10.1016/i.scitotenv.2015.01.008

PANAGOS, P.; BORRELLI, P.; MEUSBURGER, K.; YU, B.; KLIK, A.; JAE LIM, K.; ... BALLABIO, C. Global rainfall erosivity assessment based on high-temporal resolution rainfall records. Scientific Reports, v. 7, n. 1, p. 1-12, 2017. https://doi.org/10.1038/s41598-017-04282-8

PEREIRA FILHO, A. J.; VEMADO, F.; VEMADO, G.; GOMES VIEIRA REIS, F. A.; GIORDANO, L. DO C.; CERRI, R. I.; ... AMARAL, C. DOS S. A Step towards Integrating CMORPH Precipitation Estimation with Rain Gauge Measurements. Advances in Meteorology, v. 20, n. 8, p. 1-24, 2018. https://doi.org/10.1155/2018/2095304 
RENARD, K. G.; FREIMUND, J. R. Using monthly precipitation data to estimate the R-factor in the revised USLE. Journal of Hydrology, v. 157, n. 4, p. 287-306, 1994. https://doi.org/10.1016/0022$\underline{1694(94) 90110-4}$

RINGARD, J., BECKER, M., SEYLER, F., LINGUET, L. Temporal and Spatial Assessment of Four Satellite Rainfall Estimates over French Guiana and North Brazil. Remote Sensing, v. 7, n. 12, p. 16441-16459, 2015. https://doi.org/10.3390/rs71215831

RIQUETTI, N. B.; MELLO, C. R.; BESKOW, S.; VIOLA, M. R. Rainfall erosivity in South America: Current patterns and future perspectives. Science of The Total Environmental, v. 13, n. 2, p. 1-14, 2020. https://doi.org/10.1016/j.scitotenv.2020.138315

SADEGHI, S. H.; ZABIHI, M.; VAFAKHAH, M.; HAZBAVI, Z. Spatiotemporal mapping of rainfall erosivity index for different return periods in Iran. Natural Hazards, v. 87, n. 1, p. 35-56, 2017. https://doi.org/10.1007/s11069-017-2752-3

SANTOS, M. R. S.; VITORINO, M. I.; PEREIRA, L. C. C. Spatiotemporal variation in the precipitation of the Amazon coastal zone: use of remote sensing and multivariate analysis. Revista de Climatologia, v. 25, n. 2, p. 35-53, 2019. https://doi.org/10.5380/abclima.v25i0.64892

SANTOS SILVA, D. S.; BLANCO, C. J. C.; SANTOS JUNIOR, C. S.; MARTINS, W. L. D. Modeling od the spatial and temporal dynamics of erosivity in the Amazon. Modeling Earth Systems and Environmental, v. 6, n. 1, p. 513-523, 2019. https://doi.org/10.1007/s40808-019-00697-6

SILVA JUNIOR, C.; ALMEIDA, C.; SANTOS, J.; ANDERSON, L.; ARAGÃO, L.; SILVA, F. Spatiotemporal Rainfall Trends in the Brazilian Legal Amazon between the Years 1998 and 2015. Water, v. 10, n. 3, p. 1220-1233, 2018. https://doi.org/10.3390/w10091220

SOBRAL-SOUZA, T.; VANCINE, M. H.; RIBEIRO, M.; LIMA-RIBEIRO, M. S. Efficiency of protected areas in Amazon and Atlantic forest conservation: A spatio-temporal view. Acta Oecologica, v. 87, n. 1, p. 1-7, 2018. https://doi.org/10.1016/..actao.2018.01.001

SOUTO, J. I. O.; TRINDADE, A. R.; TAVARES, P. A.; BELTRÃO, N. E. S.; PONTES, A. N. Temporal patterns of precipitation and vegetation variability over Iriri River basin during EI Niño/Southern Oscilation. Revista Brasileira de Geografia Física, v. 12, n. 3, p. 789-800, 2019. https://doi.org/10.26848/rbgf.v12.3.p789-800

SOUTO, J. I. O.; BELTRÃO, N. E. S.; OLIVEIRA, R. M. S. Drought assessments trough remote sensing in the Marajó Archipelago: A spatial data interpretation of CPC MORPHING technique. Boletim Goiano de Geografia, v. 39, n. 2, p. 1-25, 2019. https://doi.org/10.5216/bgg.v39i0.55910

TEJADA, G.; GÖRGENS, E. B.; ESPÍRITO-SANTO, F. D. B.; CANTINHO, R. Z.; OMETTO, J. P. Evaluating spatial coverage of data on the aboveground biomass in undisturbed forests in the Brazilian Amazon. Carbon Balance and Management, v. 14, n. 1, p. 1-18, 2019. https://doi.org/10.1186/s13021-019-0126-8

TENG, H.; MA, Z.; CHAPPELL, A.; SHI, Z.; LIANG, Z.; YU, W. Improving Rainfall Erosivity Estimates Using Merged TRMM and Gauge Data. Remote Sensing, v. 9, n. 11, p. 1134-1143, 2017. https://doi.org/10.3390/rs9111134

TERASSI, P. M. B.; OLIVEIRA-JÚNIOR, J. F.; GOIS, G.; OSCAR JÚNIOR, A. C.; SOBRAL, B. S.; BIFFI, V. H. R.; ... VIJITH, H. Rainfall erosivity in the municipality of Rio de Janeiro - Brazil. Urban Climate, v. 33, n. 2, p. 1-23, 2020. https://doi.org/10.1016/j.uclim.2020.100637

TORRALBA, V.; RODRÍGUEZ-FONSECA, B.; MOHINO, E.; LOSADA, T. The non-stationary influence of the Atlantic and Pacific Niños on North Eastern South American rainfall. Frontiers in Earth Science, v. 3, n. 1, p. 55-61, 2015. https://doi.org/10.3389/feart.2015.00055

TRINDADE, A. L. F.; OLIVEIRA, P. T. S.; ANACHE, J. A. A.; WENDLAND, E. Spatial variability of rainfall erosivity in Brazil. Pesquisa Agropecuária Brasileira, v. 51, n. 2, p. 1918-1928, 2016. https://doi.org/10.1590/s0100-204x2016001200002

VRIELING, A.; HOEDJES, J. C. B.; VAN DER VELDE, M. Towards large-scale monitoring of soil erosion in Africa: Accounting for the dynamics of rainfall erosivity. Global and Planetary Change, v. 115, n. 3, p. 33-43, 2014. https://doi.org/10.1016/j.gloplacha.2014.01.009 
WARD, P. J.; EISNER, S.; FLÖRKE, M.; DETTINGER, M. D.; KUMMU, M. Annual flood sensitivities to El Niño-Southern Oscillation at the global scale. Hydrology and Earth System Sciences, v. 18, n. 1, p. 47-66, 2014. https://doi.org/10.5194/hess-18-47-2014

ZUBIETA, R.; GETIRANA, A.; ESPINOZA, J. C.; LAVADO-CASIMIRO, W.; ARAGON, L. Hydrological modeling of the Peruvian-Ecuadorian Amazon basin using GPM-IMERG satellite-based precipitation dataset. Hydrology and Earth System Sciences, v. 21, n. 2, p. 3543-3555, 2017.

https://doi.org/10.5194/hess-21-3543-2017

Recebido em: 07/10/2020

Aceito para publicação em: 25/01/2021 